\title{
The Relationship between Producer Service and Local Manufacturing Industry: Empirical Evidence from Shanghai
}

\author{
Shouming CHEN, Jie LI, Meijuan JIA \\ School of Economics and Management, Tongji University, Shanghai, China. \\ Email: schen@tongji.edu.cn
}

Received March $11^{\text {th }}$, 2009; revised May $13^{\text {th }}$, 2009; accepted July $17^{\text {th }}, 2009$.

\begin{abstract}
Previous studies suggested that the development of producer service resulted from manufacturing outsourcing. On the other hand, competitive producer service can promote the progress of manufacturing industry. Theoretically, correlation may exist between them. According to co-integration theory, this paper empirically tests the time series data collected from both producer service and manufacturing industry in Shanghai, indicating that co-integration does exist between producer service and local manufacturing industry. Empirical results of this paper partially support the conclusions of prior studies addressed above.
\end{abstract}

Keywords: producer service, manufacturing industry, co-integration testing, empirical analysis, shanghai

\section{Introduction}

Producer service is one of the modern service industries that have been the forces promoting economic development in developed countries. Progress in producer service industry not only benefits itself but also significantly facilitates advanced manufacturing industry. A generally accepted view is that advanced manufacturing industry could not exist in China without the presence of advanced producer service. Subsequently, it is much more difficult for manufacturing industry to maintain comparable and competitive advantages. Therefore, it seems reasonable to suppose that core cities such as Shanghai should promote modern services mainly composed of producer service to serve manufacturing industry better in adjacent provinces and other parts of China. Is this assumption rational? Additionally, whether producer service in Shanghai really serves manufacturing industry in adjacent provinces and other parts of China need further and deeper investigation. This paper conducts empirical analysis and tries to briefly answer these questions.

\section{Theories and Hypothesis}

Previous literatures define producer service from two perspectives. One definition focuses on objected ac- cepted services. Greenfield mentions that producer service mainly serves enterprises, non-profit organizations, and governments, rather than offering products and services to end users [1]. Harrington and Lombard state that producer server offer intermediate services to enterprises. [2] Stull and Madden suggest that producer service assists enterprises or organizations to offer other products or services, rather than providing services to private sectors or family sectors [3]. The other definition focuses on services that producer service can offer. This definition is an extension of original concept. According to Browning and Singleman, producer service is mainly composed of knowledge-intensive industries, for instance, finance, insurance, legal industry, and so forth [4]. Howells and Green state that producer service functions as intermediate agency promoting operational efficiency and bringing value to production and other services [5]. Daniels concludes several existing classifications of producer service and suggests that producer service could be classified to three categories. The first category is information processing service involved of banking, insurance, marketing, accounting, asset management, advertising, and information editing skill. The second is services related to business, such as sales, traffic management, installation and maintenance of basic equip- 
ments, and maintenance and servicing for communication equipment. The third category refers to personal support services, for example, welfare, food supply, individual travel, and residence [6].

Basically, producer service can be characterized by following traits. The first trait is intermediate input, indicating producer service does not serve to end users but promotes intermediate consumption in order to create more value. The second is relatively stronger industrial correlation in agriculture, manufacturing, and other industries. Third, most services producer service provides are technology-intensive or knowledge-intensive and contain more stock of human resource. Forth, producer service trends external, suggesting that internal programs continually depart from original enterprises and become professional services providers that are independent to original enterprises. Thus, kinds of producer service increase quickly.

Many researches conducted before explain the reason why producer service progresses so fast. Using input-output methodology, Tschetter investigates postwar producer service and tries to find why it progresses so quickly. Among many reasons, that ways of enterprises doing business changed is an important explanation. Unbundling of production has a more significant impact [7]. Coffey and Bailly analyze extemalization of producer service, suggesting that six factor including internal technological limits and risk aversion lead manufacturing and services providers buy producer services from outside [8]. According to transaction cost theory, some scholars of New Institutional Economics analyze producer services outsourcing $[9,10]$, and subsequently state that enterprise prefers outsourcing due to cost reduction resulted from outsourcing and that external transaction costs are less than internal costs due to impacts of economy of scale. Meanwhile, outsourcing can effectively reduce risk. Some researchers analyze producer services from strategic perspective, suggesting that risk and uncertainty could be reduced by outsourcing and that through outsourcing enterprises can concentrate available resources on the most competitive phases in value chain and then gain advantages [11]. Correlation between producer service and manufacturing industry is another focus to which researchers pay much attention. Though no consensus on this topic has reached, most researchers agree that producer service promote manufacturing industry. Additionally, some researchers state that essences for the development of manufacturing industry are external to itself [12] and that further achievements of Chinese manufacturing industry could not reached without advanced producer service.
Therefore, we can conclude: producer service is resulted from outsourcing of manufacturing enterprises. Subsequently, scale of manufacturing industry determines the scale of producer service to a certain extent. Thus, we get the hypothesis of this analysis.

Hypothesis: Scale of producer service in Shanghai positively relates to scale of local manufacturing industry in Shanghai.

\section{Method and Data}

\subsection{Data Collection}

It is difficult to collect appropriate data from producer service to conduct empirical analysis for a long time. In early studies, researchers just simply combine the output of sub-sectors in service industry and then use the combination as the output of producer service; however, there is no agreement on which subsector is appropriate to be classified into producer service. A normal used classification is composed of finance, insurance, business services, and real property industry. Impertinency of this classification can be found easily. First, it does not include services of other services industries offered to enterprises. Second, most services offered by these industries addressed above are consumed by end users, for example, houses of real property industry and personal financial services.

We estimate producer services output by subtracting consumer and government services output from total service sector output, using a technique first developed by Grubel and Walker [13]. Tao and Wong used the technique to estimate producer service in Hong Kong [14]. Steps of using this method will address below. All sorts of services industries can be classified into three categories. The first offering service to enterprise belongs to producer service. The second offers service to government and the third to end users. The amount of service offered to end users can be estimated by the total amount end users pay annually. We suppose that the amount that end users outside Shanghai pay for service offered by local providers is equal to the amount that end users in Shanghai pay for service offered by ecdemic providers. We combine service offered to government into producer service because the amount of services offered to governments is relative fewer. In other words, we estimate the annual its value added or GDP of producer service by deducting payout that Shanghai end users pay for service they receive from the annual GDP that all services industries create.

Data collected and used in this study are listed in Table 1. 
Table 1. Value added of producer service and gross output value of manufacturing industry (1980-2004) (Calculated at current prices)

\begin{tabular}{lcc}
\hline Year & Nominal value added of producer service & $\begin{array}{l}\text { Nominal gross output value of manufacturing in- } \\
\text { dustry }\end{array}$ \\
\hline 1980 & 60.40 & 560.75 \\
1981 & 64.26 & 575.97 \\
1982 & 68.44 & 590.39 \\
1983 & 76.46 & 614.96 \\
1984 & 90.56 & 678.62 \\
1985 & 112.22 & 791.31 \\
1986 & 124.17 & 871.06 \\
1987 & 146.20 & 970.00 \\
1988 & 173.67 & 1157.80 \\
1989 & 184.45 & 1341.96 \\
1990 & 221.03 & 1442.35 \\
1991 & 283.50 & 1703.96 \\
1992 & 369.85 & 2091.66 \\
1993 & 520.98 & 2809.20 \\
1994 & 710.71 & 3543.66 \\
1995 & 905.87 & 4425.66 \\
1996 & 1130.39 & 4835.10 \\
1997 & 1412.99 & 6094.83 \\
1998 & 1631.75 & 6151.95 \\
1999 & 1821.70 & 6409.07 \\
2000 & 2084.26 & 7467.26 \\
2001 & 2261.86 & 8243.64 \\
2002 & 2446.84 & 9088.32 \\
2003 & 2676.27 & 11799.35 \\
2004 & 3117.12 & 14759.49 \\
\hline
\end{tabular}

Source: Author collected and rearranged from Shanghai Statistical Yearbook, 1980-2005.

Data of manufacturing industry in Table 1 are based on the gross output value and those of producer service are based on value added (GDP) due to the availability of data collected from statistical yearbook. All the data are calculated at current prices. Data of manufacturing industry changed from 1995 relatively significantly because statistical method changed in that year. Value added tax is excluded from 1995. Thus we found two types of data in 1996's Shanghai Statistical Yearbook, one including value added tax and the other excluding value added tax. We compared these data and made some modifications to the data after 1996. A national economic survey was conducted in 2004, leading to significant change in the data of services industry. In the same way, we modified the data of producer service before 2004. Table 1 lists the data after modification.

\subsection{Data Rearrangement}

Based on data in Table 1, Figure 1 illustrates how value added of producer service and gross output value of manufacturing industry changed annually. We can see clearly that trend of producer service resembles that of manufacturing industry. In other words, both of the data are non-stationary time series, respectively.

To control for the impact of price index on nominal value, each value added of producer service of these 25 years was transformed to the value at 1980 constant prices, so was the gross output value of manufacturing industry. These transformations were completed by using Consumer Price Index (CPI). Table 2 shows the results of these transformations.

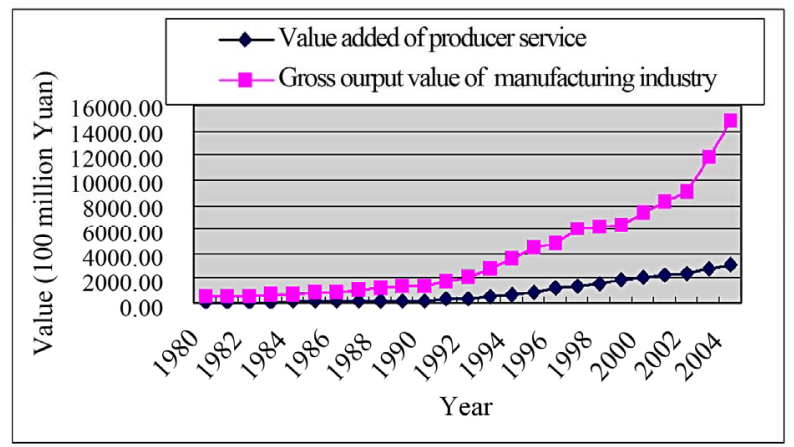

Figure 1. Producer service and manufacturing industry in Shanghai (1980-2004) 
Table 2. Value added of producer service and gross output value of manufacturing industry (1980-2004) (Calculated at 1980 constant prices)

\begin{tabular}{lcc}
\hline Year & $\begin{array}{l}\text { Actual value added of producer service } \\
\left(\mathbf{P S}_{\mathbf{t}}\right)\end{array}$ & $\begin{array}{l}\text { Actual gross output value of manufacturing } \\
\text { industry } \mathbf{( M}_{\mathbf{t}} \mathbf{)}\end{array}$ \\
\hline 1980 & 60.40 & 560.75 \\
1981 & 63.42 & 568.52 \\
1982 & 67.30 & 580.61 \\
1983 & 75.06 & 603.67 \\
1984 & 86.98 & 651.79 \\
1985 & 93.58 & 659.84 \\
1986 & 97.39 & 683.17 \\
1987 & 106.10 & 703.96 \\
1988 & 104.95 & 699.65 \\
1989 & 96.14 & 699.44 \\
1990 & 108.38 & 707.28 \\
1991 & 125.80 & 756.14 \\
1992 & 149.20 & 843.77 \\
1993 & 174.86 & 942.87 \\
1994 & 192.54 & 960.00 \\
1995 & 206.74 & 1010.04 \\
1996 & 236.24 & 1010.50 \\
1997 & 287.27 & 1239.14 \\
1998 & 331.75 & 1250.75 \\
1999 & 364.89 & 1283.74 \\
2000 & 407.33 & 1459.32 \\
2001 & 442.04 & 1611.05 \\
2002 & 476.44 & 1769.66 \\
2003 & 519.89 & 2292.11 \\
2004 & 592.71 & 2806.46 \\
\hline
\end{tabular}

$\mathrm{PS}_{\mathrm{t}}$ refers to value added of producer service and $\mathrm{M}_{\mathrm{t}}$ to gross output value of manufacturing industry. We found that each logarithm of the two time series is linear. Subsequently, we used unit root test to figure out whether the time series is stationary and the order of integration of non-stationary series. Among commonly used unit root test such as DF test, ADF test, and Philips non-parameter test (PP test), ADF test based on residual analysis and introduced by Engle and Granger was adapted in this study. We used Eviews4.0 to conduct this test and found that $\ln \left(\mathrm{PS}_{\mathrm{t}}\right)$ and $\ln \left(\mathrm{M}_{\mathrm{t}}\right)$ are non-stationary. However, $\ln \left(\mathrm{PS}_{\mathrm{t}}\right)$ and $\ln \left(\mathrm{M}_{\mathrm{t}}\right)$ became stationary after first order differencing, which means that $\ln \left(\mathrm{PS}_{\mathrm{t}}\right)$ and $\ln \left(\mathrm{M}_{\mathrm{t}}\right)$ are series of integration of Order 1, respectively.

\subsection{Co-integration Testing}

For two series of integration of order 1, we used the Engle-Granger two-step approach to test the co-integration relationship.

First, we used $\ln \left(\mathrm{PS}_{\mathrm{t}}\right)$ as the dependent variable and established the regression equation below,

$$
\ln \left(P S_{t}\right)=\beta_{0}+\beta_{1} \ln \left(M_{t}\right)+u_{t}
$$

after estimation we got Equation (2),

$$
\begin{aligned}
& \ln \left(P S_{t}\right)=-5.67+1.58 \ln \left(M_{t}\right)+\hat{u}_{t} \\
& \mathrm{t} \quad(-10.5) \quad(20.06) \\
& \mathrm{R}^{2}=0.95 \text {, Adjusted } \mathrm{R}^{2}=0.94 \text {, D.W. }=0.35
\end{aligned}
$$

Figures in parentheses under Equation (2) are corresponding t values. Coefficient in Equation (2) shows that when gross output value of manufacturing industry increases $1 \%$, value added of producer service increases $1.58 \%$.

Second, we used unit root test to evaluate residuals of Equation (2) and got,

$$
\hat{u}_{t}=\ln \left(P S_{t}\right)-1.58 \ln \left(M_{t}\right)+5.67
$$

Table 3. Results of unit root test to $\hat{u}_{t}$

\begin{tabular}{cccc}
\hline ADF test statistic & -3.310353 & $\begin{array}{c}1 \% \\
\text { Critical value* }\end{array}$ & -3.9635 \\
\hline & $\begin{array}{c}5 \% \\
\text { Critical value }\end{array}$ & -3.0818 \\
\hline & $\begin{array}{cc}10 \% \\
\text { Critical value }\end{array}$ & -2.6829 \\
\hline
\end{tabular}

*MacKinnon critical values for rejection of hypothesis of a unit root. 
We also used unit root test to test. According to AIC and SC principle, the best lag order is 9. Test results are showed in Table 3.

Test results in Table 3 suggest that $\hat{u}_{t}$ rejects $\mathrm{H}_{0}$ at the $5 \%$ significance, showing that no unit root exists. Thus, $\hat{u}_{t}$ is a stationary series, which means $\hat{u}_{t} \sim I(0)$. Co-integration exists between $\ln \left(\mathrm{PS}_{\mathrm{t}}\right)$ and $\ln \left(\mathrm{M}_{\mathrm{t}}\right)$, and Co-integrated vector is $(1,-1.58)$.

\subsection{Result and Analysis}

The empirical result shows a long-term relationship between producer service and local manufacturing industry in Shanghai. Namely, it is possible that Shanghai's producer service interrelates with the development of local manufacturing industry. Such empirical result is inconsistent with Shanghai's future industry direction that Shanghai as an important metropolis in China should focus on the development of modern producer service, not on the development of manufacturing industry. The potential premise behind producer service oriented strategy of Shanghai relies on the footloose trait of advanced producer service. In the other word, the advanced producer service is not limit to the condition of factor of production and to the adjacency of market and raw material. However, the empirical result from Wernerheim and Sharpe who study the footlooseness of producer service in metropolitan Canada does not support the premise [15]. They found that the advanced producer service, such as Information, Communication and Technology (ICT) sector, is not as footloose as expected [15]. Further, the result of this paper is consistent with the result from Wernerheim and Sharpe and shows that the producer service is insignificantly footloose and that the producer service has a long-term relationship with local manufacturing industry. Local manufacturing industry in Shanghai promotes the development of producer service in Shanghai.

\section{Conclusions}

Based on data collected from Shanghai, this empirical study with time series analysis shows that co-integration do exist between producer service and local manufacturing industry, partially supporting the hypothesis that producer service interrelates with manufacturing industry. The conclusion is also meaningful for other cities or provinces in china to formulate the strategy of producer service development. Meanwhile, we recognize the limitations in the application of our conclusion. First of all, the conclusion of this study based on data collected from Shanghai only represent the situation in a specific past period not the future situation. For example, the relationship between producer service and manufacturing industry may vary after the elimination of regional collaboration barrier. Second, we did not consider a relationship between the producer service in shanghai and the manufacturing industry in Yangtze delta. If the relationship is positive, the development of producer service in shanghai could also be explained by the growing scale of manufacturing industry in Yangtze delta. This is our future research issue.

The domain that producer service in Shanghai serviced may cover a much larger area, from Yangtze delta to the whole country, even the whole world. However, we could not have a blind faith in the footloose trait of advanced producer service. In the regional development, the strategy that coordinates both developments of local producer service and local manufacturing industry should be persisted constantly.

\section{REFERENCES}

[1] H. L. Greenfield, "Manpower and the growth of producer services,” Columbia University Press, New York, 1966.

[2] J. W. Harrington and J. R. Lombard, "Producer-service firms in a declining manufacturing region,” Environment and Planning A, No. 21, pp. 65-79, 1989.

[3] W. Stull and J. Madden, "Post-industrial Philadelphia: Structural changes in the metropolitan economy Philadelphia,” University of Pennsylvania, 1990.

[4] H. C. Browning and J. Singelmann, "The emergence of a service society,” National Technical Information Services, Springfield, 1975.

[5] J. Howells and A. Green, "Location, technology and industrial organization in UK services,” Progress in Planning, Vol. 26, No. 2, pp. 83-184, 1986.

[6] P. W. Daniels, "Service industries in the world economy,” Blackwell Publishers, 1993.

[7] J. Tschetter, "Producer services industries: Why are they growing so rapidly?” Monthly Labor Review, Vol. 110, No. 12, pp. 31-40, 1987.

[8] C W. J. offey and A. S. Bailly, "Producer services and flexible production: An exploratory analysis,” Growth and Change, Vol. 22, No. 4, pp. 95-117, 1991.

[9] P. W. Daniels, “The geography of services,” Progress in Human Geography 9, pp. 443-451, 1985.

[10] W. R. Goe, "Producer services, trade and the social division of labor [J],” Regional Studies, No. 24, pp. 327-342, 1990.

[11] W. J. Coffey and J. J. McRae, "Services industries in 
regional development," Institute for Research on Public Policy, Montreal, 1990.

[12] C. Q. Guo, "Evolution of manufacturing model and tendency of manufacturing development, doctorate forum of Anhui manufacturing development," Hefei University of Technology Publishing House (in Chinese), 2004.

[13] H. G. Grubel and M. A. Walker, "The Canadian service industries [M],” The Fraser Institute, Vancouver, 1989.
[14] Z. G. Tao and Y. C. R. Wong, "Hong Kong: From an industrialized city to a centre of manufacturing-related service [J],” Urban Studies, Vol. 39, No. 12, pp. 23452358, 2002.

[15] C. M. Wernerheim and C. A. Sharpe, “'High order’ producer services in metropolitan Canada: How footloose arethey?” Regional Studies, No. 37, pp. 469-490, 2003. 